\title{
Henoch-Schonlein Purpura in 1-12 years old Children In Sulaimaniyah City, Kurdistan Regional Government Of Iraq
}

\author{
Dr. Hayder Fakhir
}

Dr. Sherko Babakir Mina

\section{$\underline{\text { Abstract }}$}

Background: Henoch-Schönlein purpura is an acute immunoglobulin A (IgA)-mediated disorder characterized by a generalized vasculitis involving the small vessels of the skin, gastrointestinal (GI) tract, kidneys, joints, and rarely the lungs and the central nervous system (CNS).

Objectives: An attempt to identify the characteristics of this disease that is considered as quite common problem in our city, to identify the epidemiological, clinical, laboratory features and complications of HSP in our locality and to find the mode of treatments used by pediatricians and trying to uniform the management in a scientific way.

Patients and Methods: Sixty five patients with HSP hospitalized in Sulaimaniyah pediatric Teaching Hospital in Kurdistan/ Iraq were included in this retrospective study from $1^{\text {st }}$ of January 2013 to $31^{\text {st }}$ of December 2014; they were selected by Case sheets based on the diagnosis of HSP at discharge time.

Results: Of 65 patients, 37 (56.9\%) were boys and 28 (43.1) were females, with a male to female ratio of 1.3:1. The patients' ages ranged from (2 to 12) years, with a mean of 6 years. Approximately $61 \%$ of cases were presented during winter and spring. Upper respiratory tract infection preceded HSP in $(36.9 \%)$ of the patients. The main clinical features included skin rash $(100 \%)$, skeletal manifestation (66\%), gastrointestinal manifestation (70.8\%), renal involvement (26.16\%), and Genital involvement $(5.4 \%)$ in males. Fecal occult bloods were positive in $10 / 29(34.5 \%)$ of the patients. Forty one (63\%) patients received corticosteroid therapy.

Conclusions: There were no major differences in the epidemiological and clinical criteria of HSP in Sulaimaniyah with that most of similar studies done elsewhere. GIT involvement more common than skeletal involvement. Many patients had been treated with corticosteroid therapy. 
Thi-Qar Medical Journal (TQMJ):Vol.(19), No.(1), 2020

Web Site: https://jmed.utq.edu.iq

Email:utjmed@utq.edu.iq

ISSN (Print):1992-92 18, ISSN (Online):1992-92 18

DOI: https://doi.org/10.32792/utq/utjmed/19/1/11

\section{Introduction}

Henoch-Schönlein purpura (HSP; also referred to as Schönlein-Henoch purpura, anaphylactoid purpura, or purpura rheumatica) is an acute immunoglobulin A (IgA)-mediated disorder characterized by a generalized vasculitis involving the small vessels of the skin, the gastrointestinal (GI) tract, the kidneys, the joints, and rarely the lungs and the central nervous system (CNS). ${ }^{(1,2,)}$

The first description of this disorder was probably that of a young boy with "bloody points" over the shins of his legs, abdominal pain, blood in the stools and urine and painful subcutaneous edema, described by William Heberden in 1801.

In 1837 Johann Scho"nlein described the association of purpura and joint pain as "Peliosis rheumatica', Eduard Henoch, Scho“nlein's former student noted gastrointestinal involvement in association with purpura and arthritis in 1868 and subsequently he recorded renal involvement too. ${ }^{(3)}$

HSP occurs worldwide and affects all ethnic groups. The incidence of HSP is estimated at 14- 20/100,000 children per year and affects males more than females, with a 1.2-1.8 1 male to female ratio. Approximately $90 \%$ of HSP cases occur in children usually between the ages of 3 and $10 \mathrm{yr}$. HSP is distinctly less common in adults in whom severe and chronic complications are often encountered. HSP is more common in the fall, winter, or spring and is unusual in summer months. Many cases of HSP follow a documented upper respiratory infection ${ }^{(4)}$ other infectious agents, vaccinations, and insect bites also have been implicated as possible triggers for HSP (IgAV) ${ }^{(5)}$. The rate of HSP (IgAV) is significantly higher (approximately 5 percent) in patients with familial Mediterranean fever ${ }^{(6,7)}$.

The etiology of HSP remains to be clearly defined but is thought to be multifactorial, with genetic, environmental, and antigenic components.

More than $75 \%$ of patients report antecedent URTI, pharyngeal infection, or GI infection. Multiple bacterial and viral infectious agents have been associated with the development of HSP, and cases also have been reported after drug ingestions and vaccinations ${ }^{(8)}$.Several triggering agents have been proposed (Table 1): 
Thi-Qar Medical Journal (TQMJ):Vol.(19), No.(1), 2020

Web Site: https://jmed.utq.edu.iq

Email:utjmed@utq.edu.iq

ISSN (Print):1992-92 18, ISSN (Online):1992-92 18

DOI: https://doi.org/10.32792/utq/utjmed/19/1/11

Table: Triggering factors of $\operatorname{HSP}^{(9,10,11)}$

\begin{tabular}{|c|c|}
\hline Group & Triggering factors \\
\hline Bacteria & $\begin{array}{l}\text { Streptococcus-pyogen, Staphylococcus-aureus, MycoPlasma, Shigella, } \\
\text { Yesinia, Salmonella, Legionella, Campylobacter, Helicobacter- pylori. }\end{array}$ \\
\hline Viruses & $\begin{array}{l}\text { Parvovirus, Adenovirus, Hepatitis B, Epstein-Barr, Varicella, HSV, HIV, } \\
\text { Coxsakei. }\end{array}$ \\
\hline Drugs & $\begin{array}{l}\text { Ampicillin, Erythromycin, Penicillin, Quinidine, Quinine, Losartan, and } \\
\text { Cytarabine. }\end{array}$ \\
\hline Others & Insect bites, Food allergy, Toxocara canis. \\
\hline Vaccinations & $\begin{array}{l}\text { Measles, TB, Yellow fever, HB, Influenza, Pneumococcal, Meningococcal, } \\
\text { Cholera. }\end{array}$ \\
\hline
\end{tabular}

Pathogenesis of Henoch-Schönlein purpura is not clearly understood,but it is known to be an IgA-complex-mediated disease $^{(12)}$. IgA is the main immunoglobulin directed against viral and bacterial antigens in the mucosal immune system, and $\operatorname{IgA}$ complexes are formed and deposited in the skin, bowel and kidney glomeruli, triggering a localized inflammatory response. Serum concentrations of $\operatorname{IgA}$ have been described that Increases in over half of the patients with $\operatorname{HSP}^{(13,14)}$.

The clinical presentation of HSP includes: : purpura, arthritis and abdominal pain are known as the "classic triad" of HenochSchönlein purpura, the clinical features are the following:

\section{Skin manifestation}

The hallmark of HSP is its rash: palpable purpura caused by small vessel inflammation in the skin leading to extravasations of blood into the surrounding tissues, frequently with IgA deposition.(15) starting as pink macules or wheals and developing into petechiae, raised purpura, or larger ecchymoses. Occasionally, bullae and ulcerations develop. The skin lesions are usually symmetric and occur in gravitydependent areas (lower extremities) or on pressure points (buttocks), the skin lesions often evolve in groups, typically lasting 3-10 days, and may recur up to 4 mo after initial presentation. Subcutaneous edema localized to the dorsa of hands and feet, periorbital area, lips, scrotum, or scalp is also common (4). 
Web Site: https://jmed.utq.edu.iq

ISSN (Print):1992-92 18, ISSN (Online):1992-92 18

DOI: https://doi.org/10.32792/utq/utjmed/19/1/11
Email:utjmed@utq.edu.iq

\section{Skeletal}

Musculoskeletal involvement, including arthritis and arthralgias, is common occurring in up to $75 \%$ of children with HSP

(4). Pain, edema and functional limitation of the joint indicate joint involvement in HSP, which typically affects the lower limb joints and particularly the ankles and knees. The upper extremity joints may also be affected. Periarticular edema causes functional limitation of the joint, while it is unclear whether HSP can cause synovitis. Although joint involvement can be debilitating, it does not result in permanent deformity ${ }^{(13)}$.

\section{Gastrointestinal}

Gastrointestinal involvement occurs in about one half of affected children and most typically presents as mild to moderate crampy abdominal pain, thought to be due to small vessel involvement of the gastrointestinal tract leading to ischemia. Less commonly, significant abdominal distention, bloody diarrhea, intussusception, or abdominal perforation occurs and requires emergent intervention. Gastrointestinal involvement is typically seen during the acute phase of the illness. It may precede the onset of rash $^{.(15)}$.

\section{Renal}

Renal involvement occurs in one third of children with HSP, although renal involvement is mild in most cases, acute glomerulonephritis manifested by hematuria, hypertension, or acute renal failure can occur. Most cases of glomerulonephritis occur within the first few months of presentation, but rarely patients develop late renal disease, which ultimately can lead to chronic renal disease, including renal failure ${ }^{(15) .}$ Progression to end-stage renal disease is uncommon in children (1-2\%) (4) The severity of renal squeal is often not related to the severity of other manifestations ${ }^{(17)}$.

\section{Urogenital}

Scrotal involvement in boys with HSP (IgAV) range from 2 to 38 percent, rarely scrotal pain may be the presenting symptom. Clinical findings include pain, tenderness, and swelling of the involved testicle and/or scrotum ${ }^{(18)}$ There are anecdotal case reports of urethral stenosis, priapism and penile swelling associated with $\operatorname{HSP}^{(19,20)}$.

\section{Neurological and others}

Central nervous system involvement in HSP is rare. The most common manifestation is headache, followed by subtle encephalopathy with minimal changes in mental status, labile mood, apathy and hyperactivity. Seizures, intracranial hemorrhage, infarction and peripheral neuropathy have also been documented in case reports ${ }^{(21) .}$ Also pulmonary symptoms such as bleeding and interstitial lung disease have been reported in HSP patients. These symptoms are very rare, but can be fatal ${ }^{\text {(22) }}$ The diagnosis of HSP (IgAV) is usually based upon clinical manifestations of the disease; the purpose of laboratory evaluation is to exclude other diseases and to identify HSP-related complications.

Management of HSP (IgAV) is divided into supportive care, symptomatic therapy, and targeted treatment to decrease the risk of complications. In most cases HSP is mild and self-limiting, requiring only symptomatic treatment. Bed rest and analgesics may be necessary for those with acute arthralgia or abdominal pain. 
Web Site: $\underline{\text { https://jmed.utq.edu.iq }}$
Email:utjmed@utq.edu.iq

ISSN (Print):1992-92 18, ISSN (Online):1992-92 18

DOI: https://doi.org/10.32792/utq/utjmed/19/1/11

Intravenous fluids may be required in cases of severe abdominal pain and vomiting ${ }^{(23) .}$

\section{Patients and Methods}

Sixty five patients with HSP hospitalized in Sulaimaniyah pediatric Teaching Hospital in Kurdistan/ Iraq were included in this retrospective study from $1^{\text {st }}$ of January 2013 to $31^{\text {st }}$ of December 2014; they were selected by case sheets based on the diagnosis of HSP at discharge time.

Patients' data regarding age, gender, season of presentation, address(center or peripheries), complaints on admission, possible triggering factors, history of abdominal pain ,vomiting and rectal bleeding...etc in addition to clinical examination and some laboratory findings, a questionnaire paper was used for this purpose.

Diagnosis was made clinically by the presence of the typical purpuric rash with maximal distribution over the extensor surface of the legs and buttocks. Clinical examination also concentrated on the presence of joint swelling, edema over the joints, abdominal tenderness and other clinical features.

Investigations send for the patients who were included in this study like. Full blood count and urine analysis were done for all patient. Other investigations like blood urea, serum protein, urinary protein, blood lipid profiles , stool exam, fecal occult blood (FOB), ESR, CRP, serum electrolyte, bleeding time, clotting time, abdominal ultrasound, were done as indicated according to the clinical indications. ASO Titers were done for 3 patients; C3 and C4 were sent for one patient.

Most of the patients were treated symptomatically (rest, analgesia and rehydration) and some patients were treated with other mode of treatment like (steroid and immunoglobulin).

Ethical consideration has been taken in this study, all patient told that they will be included in this study and they gave their agreement.

\section{$\underline{\text { Statistical analysis }}$}

Statistical analyses were conducted using SPSS (version 21) software. Descriptive analyses of percentages of categorical variables were reported.

P-value of less than 0.05 denoted as statistically significant difference in all statistical comparisons. 
Web Site: $\underline{\text { https://jmed.utq.edu.iq }}$

ISSN (Print):1992-92 18, ISSN (Online):1992-92 18

DOI: https://doi.org/10.32792/utq/utjmed/19/1/11
Email:utjmed@utq.edu.iq

\section{$\underline{\text { Results }}$}

This is retrospective study from $1^{\text {st }}$ of January 2013 to $31^{\text {st }}$ of December 2014 of sixty five patients; the results as the followings:

\section{Epidemiological features}

Table: 1 Epidemiological feature of 65 patients diagnosed with HSP

\begin{tabular}{|c|c|c|c|c|}
\hline \multicolumn{3}{|l|}{ Variables } & $\mathbf{N}$ & $\%$ \\
\hline \multirow{6}{*}{ Age (year)• } & \multirow[b]{2}{*}{$<2 \mathrm{yrs}$} & Male & 1 & 1.5 \\
\hline & & Female & 1 & 1.5 \\
\hline & \multirow[b]{2}{*}{ (2-6)yrs } & Male & 27 & 41.5 \\
\hline & & Female & 14 & 21.5 \\
\hline & \multirow[b]{2}{*}{$>6 \mathrm{yrs}$} & Male & 9 & 13.8 \\
\hline & & Female & 13 & 20 \\
\hline \multirow[b]{2}{*}{ Gender } & \multicolumn{2}{|l|}{ Male } & 37 & 57 \\
\hline & \multicolumn{2}{|l|}{ Female } & 28 & 43 \\
\hline \multirow{4}{*}{ Seasonal distribution } & \multicolumn{2}{|l|}{ Autumn } & 16 & 24.6 \\
\hline & \multicolumn{2}{|l|}{ Winter } & 22 & 33.8 \\
\hline & \multicolumn{2}{|l|}{ Spring } & 18 & 27.7 \\
\hline & \multicolumn{2}{|l|}{ Summer } & 9 & 13.8 \\
\hline \multirow[b]{2}{*}{ Address } & \multicolumn{2}{|l|}{ Center } & 39 & 60 \\
\hline & \multicolumn{2}{|c|}{ Periphery } & 26 & 40 \\
\hline \multirow{6}{*}{$\begin{array}{l}\text { Possible triggering } \\
\text { factors }\end{array}$} & \multicolumn{2}{|l|}{ URTI } & 24 & 36.9 \\
\hline & \multicolumn{2}{|c|}{ Fever unknown origin } & 9 & 13.8 \\
\hline & \multicolumn{2}{|c|}{ Gastroenteritis } & 9 & 13.8 \\
\hline & \multicolumn{2}{|l|}{ UTI } & 1 & 1.5 \\
\hline & \multicolumn{2}{|c|}{ Chicken pox } & 1 & 1.5 \\
\hline & \multicolumn{2}{|c|}{ Unknown } & 21 & 32.3 \\
\hline \multicolumn{3}{|l|}{ Total } & 65 & 100 \\
\hline
\end{tabular}

- Mean standard deviation $6.00 \pm 2.729$ (minimum, maximum) $(2,12)$ yrs

In this study, the total of 65 (37 male (56.9\%) and 28 female (43.1) children were diagnosed as having HSP. The male to female ratio was 1.3:1. Their ages ranged from (2-12) years, with a mean of 6 , and median of 5 years. $3 \%$ of patients were less than 2 years of age, $63 \%$ were between (2-6) years and $33.9 \%$ more than 6 years. Peak incidence of the disease was seen in winter $(22 / 65 ; 33.8 \%)$ followed by spring $(18 / 65 ; 27.7 \%)$, autumn $(16 / 65 ; 24.6 \%)$, and summer $(9 / 65 ; 13.8 \%)$.thirty-nine $(60 \%)$ came from the center and twenty-six $(40 \%)$ came from periphery. Forty-four $(67.7 \%)$ of patients had a possible triggering factor before HSP onset. 
Web Site: https://jmed.utq.edu.iq

ISSN (Print):1992-92 18, ISSN (Online):1992-92 18

DOI: https://doi.org/10.32792/utq/utjmed/19/1/11
Email:utjmed@utq.edu.iq

Upper respiratory tract infection (URTI) preceded HSP in 24/65 (36.9\%) patients, Fever unknown origin in 9/65 (13.8\%), gastroenteritis 9/65 (13.8\%), one patient $(1.5 \%)$ had chicken pox, one patient $(1.5 \%)$ had urinary tract infection and $21 / 65(32.3 \%)$ had unknown. The main epidemiological features are shown in (Table 1).

\section{Skin}

Table: 2 Skin manifestations of 65 patients diagnosed with HSP

\begin{tabular}{|c|c|c|c|c|c|c|}
\hline \multirow{3}{*}{ Variable } & \multicolumn{4}{|c|}{ Sex } & \multicolumn{2}{|c|}{ Total } \\
\hline & \multicolumn{2}{|c|}{ Male } & \multicolumn{2}{|c|}{ Female } & \multirow[b]{2}{*}{$\mathbf{N}$} & \multirow[b]{2}{*}{$\%$} \\
\hline & $\mathbf{N}$ & $\%$ & $\mathbf{N}$ & $\%$ & & \\
\hline Lower part of the body involvement* & 21 & 32.30 & 19 & 29.20 & 40 & 61.5 \\
\hline Lower part and upper part of the body & 16 & 24.6 & 9 & 13.8 & 25 & 38.5 \\
\hline Total & 37 & 57 & 28 & 43 & 65 & 100 \\
\hline
\end{tabular}

"Classification of lower part and upper part of the body from the iliac crest.

All patients $(100 \%)$ had skin rash, distributed mainly over the legs, buttocks, and upper extremities, forty $(61.5 \%)$ patients were involved lower part of the body, twenty-five (38.5\%) patients were involved lower and upper part of the body, as shown in (table 2), but it is not statistically significant $(\mathrm{P}$ value $=0.36)$.

3. Skeletal manifestations

Table: 3 Skeletal manifestations of 65 patients diagnosed with HSP

\begin{tabular}{|c|c|c|c|c|c|c|c|}
\hline \multirow{3}{*}{\multicolumn{2}{|c|}{ Variable }} & \multicolumn{4}{|c|}{ Sex } & \multicolumn{2}{|c|}{ Total } \\
\hline & & \multicolumn{2}{|c|}{ Male } & \multicolumn{2}{|c|}{ Female } & \multirow[b]{2}{*}{$\mathbf{N}$} & \multirow[b]{2}{*}{$\%$} \\
\hline & & $\mathbf{N}$ & $\%$ & $\mathbf{N}$ & $\%$ & & \\
\hline \multicolumn{2}{|c|}{ No skeletal involvement } & 12 & 18.5 & 10 & 15.5 & 22 & 34 \\
\hline \multirow{6}{*}{$\begin{array}{l}\text { Skeletal } \\
\text { involvement }\end{array}$} & Ankle swelling & 2 & 3 & 5 & 8 & 7 & 11 \\
\hline & Wrist swelling & 1 & 1.5 & $\mathbf{0}$ & .00 & 1 & 1.5 \\
\hline & Arthralgia & $\mathbf{0}$ & .00 & 3 & 4.5 & 3 & 4.5 \\
\hline & Leg pain & $\mathbf{0}$ & .00 & 2 & 3 & 2 & 3 \\
\hline & Multiple joint involvement & 22 & 34 & 8 & 12 & 30 & 46 \\
\hline & Total of skeletal involvement & 25 & 38.5 & 18 & 27.5 & 43 & 66 \\
\hline \multicolumn{2}{|l|}{ Total } & 37 & 57 & 28 & 43 & 65 & 100 \\
\hline
\end{tabular}


Web Site: https://jmed.utq.edu.iq

ISSN (Print):1992-92 18, ISSN (Online):1992-92 18

DOI: https://doi.org/10.32792/utq/utjmed/19/1/11
Email:utjmed@utq.edu.iq

Forty-three (66\%) patients had skeletal manifestation, $25(38.5 \%)$ were male and $18(27.5 \%)$ were female as show in (Table 3), ankle swelling alone 7/65 (11\%), wrist swelling alone $1 / 65(1.5 \%)$, leg pain alone $2 / 65$ (3\%) and multiple joint involvement 30/65 (46\%) as shown in (figure 1$)$, it is statistically significant $(\mathrm{P}$ value $=0.02)$.

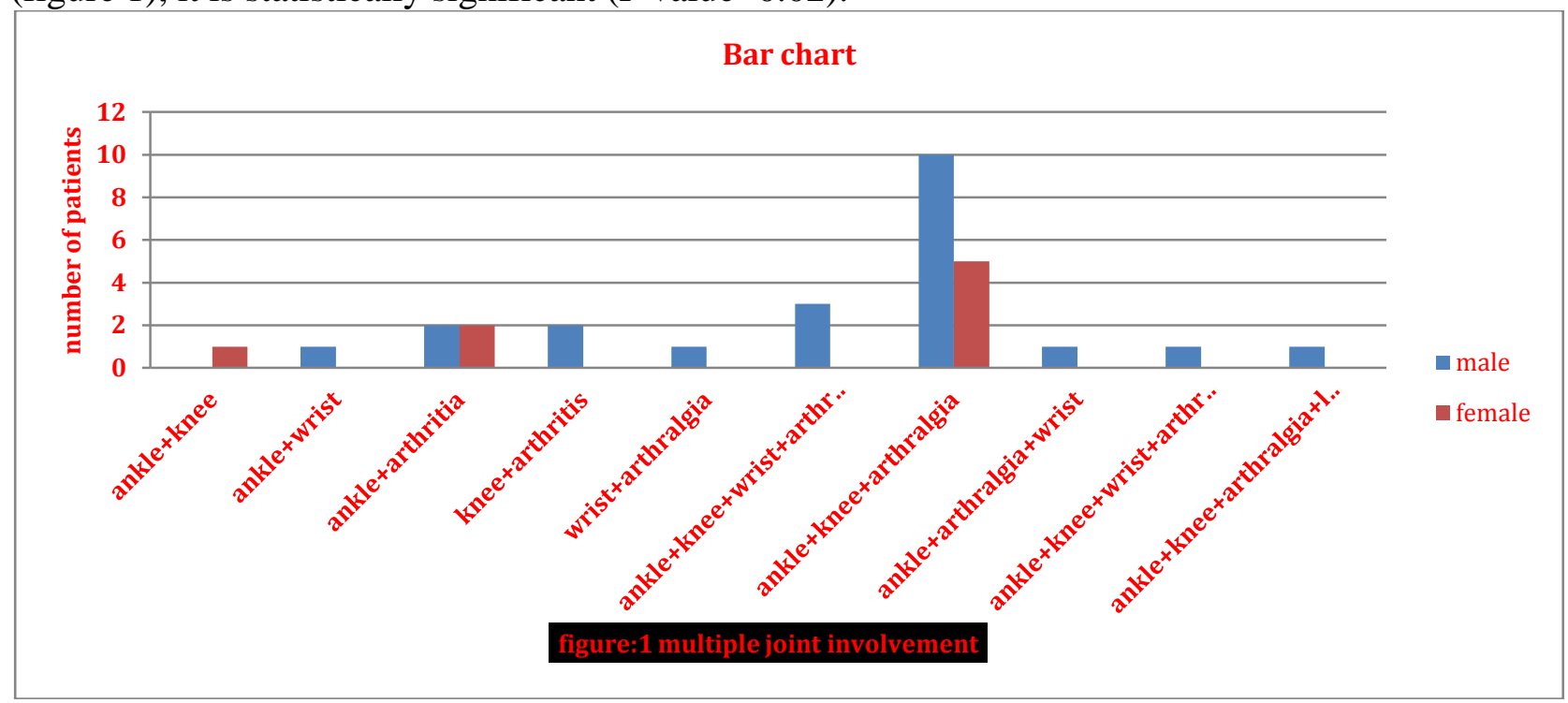

\section{Gastrointestinal manifestations}

Table: 4 Gastro-intestinal manifestations of 65 patients diagnosed with HSP

\begin{tabular}{|c|c|c|c|c|c|c|c|}
\hline \multirow{3}{*}{\multicolumn{2}{|c|}{ Variables }} & \multicolumn{4}{|c|}{ Sex } & \multicolumn{2}{|c|}{ Total } \\
\hline & & \multicolumn{2}{|c|}{ Male } & \multicolumn{2}{|c|}{ Female } & \multirow[b]{2}{*}{$\mathbf{N}$} & \multirow[b]{2}{*}{$\%$} \\
\hline & & $\mathbf{N}$ & $\%$ & $\mathbf{N}$ & $\%$ & & \\
\hline \multicolumn{2}{|c|}{ No GIT involvement } & 9 & 13.8 & 10 & 15.4 & 19 & 29.2 \\
\hline \multirow{4}{*}{ GIT involvement } & Abdominal pain(alone) & 13 & 20 & 3 & 4.6 & 16 & 24.6 \\
\hline & Nausea (alone) & 1 & 1.5 & $\mathbf{0}$ & .00 & $\mathbf{1}$ & 1.5 \\
\hline & $\begin{array}{l}\text { Multiple gastrointestinal } \\
\text { features }\end{array}$ & 14 & 21.5 & 15 & 23 & 29 & 44.5 \\
\hline & Total of GIT involvement & 28 & 43.1 & 18 & 27.7 & 46 & 70.8 \\
\hline \multicolumn{2}{|l|}{ Total } & 37 & 57 & 28 & 43 & 65 & 100 \\
\hline
\end{tabular}


Web Site: https://jmed.utq.edu.iq

ISSN (Print):1992-92 18, ISSN (Online):1992-92 18

DOI: https://doi.org/10.32792/utq/utjmed/19/1/11
Email:utjmed@utq.edu.iq

Forty -six (70.8\%) of patients had gastrointestinal features $28(43.1 \%)$ were male and $18(27.7 \%)$ were female, as shown in (Table 4),16/46 (24.6\%) had abdominal pain alone, one patient had nausea alone and 29/46 (44.5\%) had multiple gastrointestinal features that shown in (figure2) But it is not statistically significant $(\mathrm{P}$ value $=0.10)$.

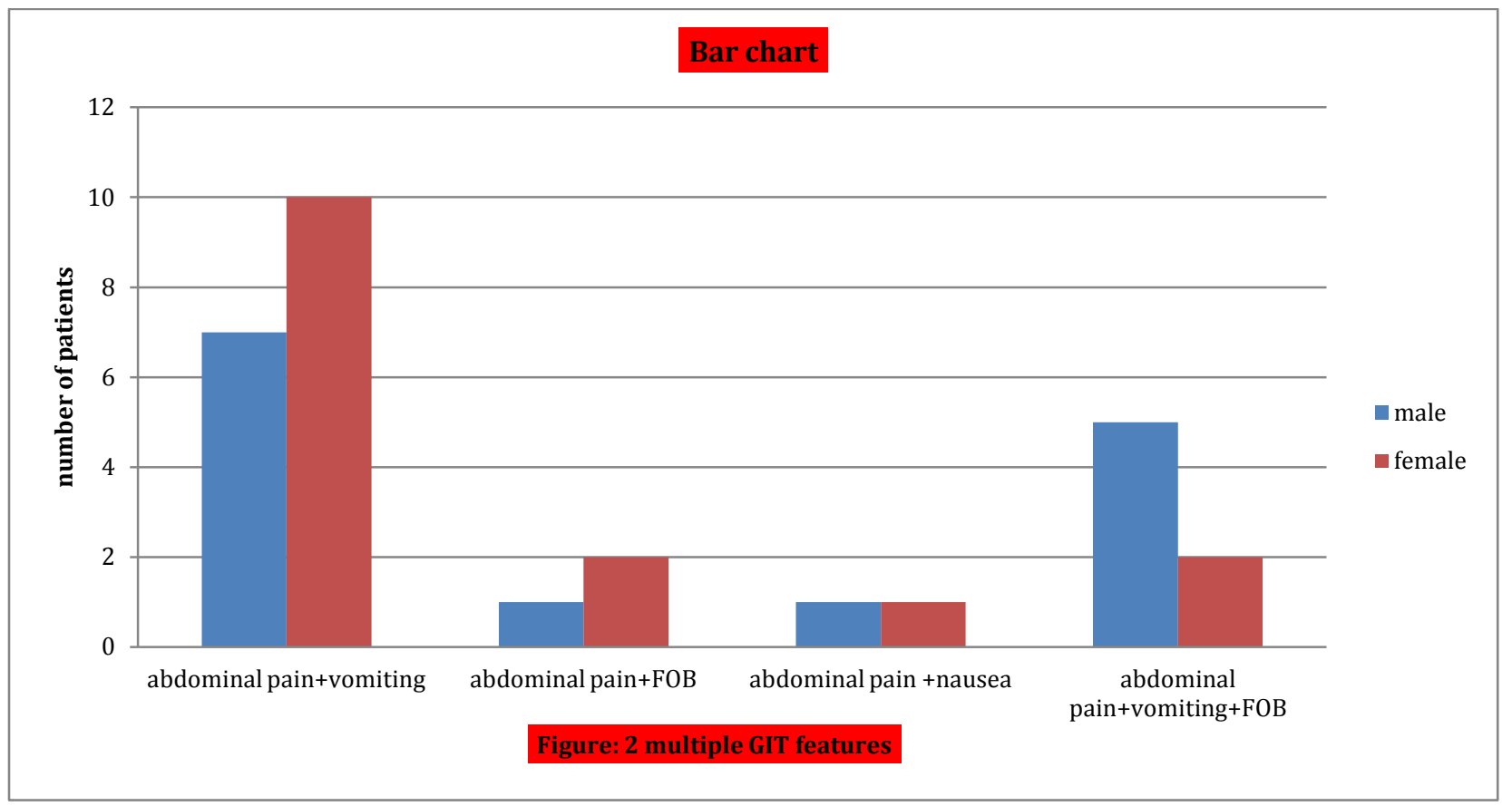

\section{Renal manifestation}

Table: 5 Renal manifestations of 65 patients diagnosed with HSP

\begin{tabular}{|c|c|c|c|c|c|c|c|}
\hline \multirow{3}{*}{\multicolumn{2}{|c|}{ Variable }} & \multicolumn{4}{|c|}{ Sex } & \multicolumn{2}{|c|}{ Total } \\
\hline & & \multicolumn{2}{|c|}{ Male } & \multicolumn{2}{|c|}{ Female } & \multirow[b]{2}{*}{$\mathbf{N}$} & \multirow[b]{2}{*}{$\%$} \\
\hline & & $\mathbf{N}$ & $\%$ & $\mathbf{N}$ & $\%$ & & \\
\hline No renal -involvem & & 27 & 41.5 & 21 & 32.3 & 48 & $\mathbf{7 3 . 8 4}$ \\
\hline \multirow{6}{*}{ Renal involvement } & Microscopic hematuria & 2 & 3 & 1 & 1.53 & 3 & 4.61 \\
\hline & Puss cells in urine & 3 & 4.6 & 1 & 1.53 & 4 & 6.15 \\
\hline & Urine $(\mathbf{R B C}+$ puss cells $)$ & 1 & 1.53 & 2 & 3 & 3 & 4.61 \\
\hline & Urine $(\mathrm{RBC}+$ puss cell $\mathrm{s}+$ hydronephrosis $)$ & 3 & 4.6 & 3 & 4.6 & 6 & 9.2 \\
\hline & $\begin{array}{l}\text { Urine }(\mathrm{RBC}+\text { Puss cells +albumin }+ \\
\text { hydronephrosis) }\end{array}$ & 1 & 1.53 & $\mathbf{0}$ & .00 & 1 & 1.53 \\
\hline & Total of renal involvement & 10 & 15.4 & 7 & 10.76 & 17 & 26.16 \\
\hline \multicolumn{2}{|l|}{ Total } & 37 & 57 & 28 & 43 & 65 & 100 \\
\hline
\end{tabular}


Web Site: $\underline{\text { https://jmed.utq.edu.iq }}$

ISSN (Print):1992-92 18, ISSN (Online):1992-92 18

DOI: https://doi.org/10.32792/utq/utjmed/19/1/11
Email:utjmed@utq.edu.iq

Seventeen patients $(26.16 \%)$ had renal involvement, $10(15.4 \%)$ patients were male and 7 $(10.76 \%)$ patients were female as shown in (Table 4), but it is not statistically significant (P value $=0.83$ ).

6. Genital involvement

Table: 6 Genital involvements of 37 patients male diagnosed with HSP

Variable

No genital involvement

Scrotal swelling and epididymitis

Total

Two patients (5.4\%) of males had scrotal swelling and epididymitis as shown in (Table 6):

7. Laboratory findings

Table: 7 Laboratory findings of 65 patients diagnosed with HSP

\begin{tabular}{|c|c|c|c|}
\hline \multicolumn{2}{|l|}{ Variables } & \multirow{2}{*}{$40^{2}$} & \multirow{2}{*}{$\begin{array}{r}\% \\
61.5\end{array}$} \\
\hline & $>11000$ & & \\
\hline WBC & $4500-11000$ & 25 & 38.5 \\
\hline \multirow{3}{*}{ PCV } & $<35$ & 24 & 36.9 \\
\hline & $35-45$ & 39 & 60 \\
\hline & $>45$ & 2 & 3.1 \\
\hline \multirow{3}{*}{ Platelet count } & $<150000$ & $\mathbf{0}$ & .00 \\
\hline & $150000-450000$ & 58 & 89.2 \\
\hline & $>450000$ & 7 & 10.8 \\
\hline \multirow[b]{2}{*}{ ESR } & $1-20$ & $20 / 36$ & 55.5 \\
\hline & $>20$ & $16 / 36$ & 44.5 \\
\hline \multirow[b]{2}{*}{ CRP } & Positive & $14 / 28$ & 50 \\
\hline & Negative & $14 / 28$ & 50 \\
\hline \multirow{5}{*}{$\mathbf{U} / \mathbf{S}$} & Normal & $15 / 31$ & 48.4 \\
\hline & Cystitis & $3 / 31$ & 9.7 \\
\hline & Mild hydronephrosis & $6 / 31$ & 19.35 \\
\hline & Mesenteric lymphadenitis & $5 / 31$ & 16 \\
\hline & Epididymitis+ scrotal edema & 2/31 & 6.45 \\
\hline \multirow{4}{*}{ GUE } & RBC >one + (alone ) & 3/58 & 5.2 \\
\hline & Puss cells >one + (alone) & $4 / 58$ & 6.9 \\
\hline & RBC + puss cells $>$ one + & 9/58 & 15.5 \\
\hline & Albumin + & 1/58 & 1.7 \\
\hline \multirow[b]{2}{*}{ Stool for occult blood } & Positive & $10 / 29$ & 34.5 \\
\hline & Negative & $19 / 29$ & 65.5 \\
\hline \multirow[b]{2}{*}{ Aso titer } & Increase & $0 / 65$ & .00 \\
\hline & Normal & $3 / 65$ & 4.6 \\
\hline \multirow{2}{*}{ C3 complement } & low & $0 / 65$ & .00 \\
\hline & Normal & $1 / 65$ & 1.5 \\
\hline \multicolumn{2}{|l|}{ Total } & 65 & 100 \\
\hline
\end{tabular}


Web Site: $\underline{\text { https://jmed.utq.edu.iq }}$

ISSN (Print):1992-92 18, ISSN (Online):1992-92 18

DOI: https://doi.org/10.32792/utq/utjmed/19/1/11
Email:utjmed@utq.edu.iq

- Leukocytosis $>11 \times 10^{9} / \mathrm{L}$ ), thrombocytosis $>450 \times 10^{9} / \mathrm{L}$, anemia when $\mathrm{PCV}<35$, Elevated ESR was defined when ESR was $>20 \mathrm{~mm} / 1$ hour, microscopic hematuria when urine $\mathrm{RBC}>+$, increased ASO titer when $>300$ IU/mm; low C3 when $<900 \mathrm{mg} / \mathrm{L}$

Forty(61.5\%) patients had Lukocytosis,24(36.9\%) patients had anemia,7(10.8\%) patients had thrombocytosis, 16/36(44.5\%) patients were increased (ESR),14/28(50\%) patients (CRP)were posative, 10/29(34.5\%) patients (FOB)were positive,3/58(5.2\%) patients had microscopic hematuria alone, 4/58(6.9\%) patients had puss-cells in the urine alone, 9/58(15.5\%)patients had (RBC and puss-cells) in the urine, just one case had albumin urea, 31(47.7\%) patients had ultrasound,15/31(48.4\%) patients u/s were normal,3/31(9.7\%)patients were cystitis,6/31(19.35\%) patients were mild hydronephrosis,5/31(16\%) patients had mesenteric lymphadenitis and just $2 / 31(6.45 \%)$ had scrotal swelling and epididymitis ),also one patient had C3-comlement but it was in normal range and $3 / 65(4.6 \%)$ patients had ASO titer but all of them in normal range, as shown in (Table 7):

\section{Mode of treatment}

Table: 8 Mode of treatment of 65 patients diagnosed with HSP

\begin{tabular}{|l|l|l|}
\hline Variables & $\mathrm{N}$ & $\%$ \\
\hline Analgesia (alone) & 16 & 24.6 \\
\hline Analgesia +steroid & 20 & 30.8 \\
\hline Analgesia +antibiotics & 8 & 12.3 \\
\hline Analgesia +steroid +antibiotics & 20 & 30.8 \\
\hline Analgesia +steroid +antibiotics +IVIG & 1 & 1.5 \\
\hline Total & 65 & 100 \\
\hline
\end{tabular}

In this study most patients were treated by (analgesia +steroid) 20(30.8\%) and 20(30.8\%) (analgesia +steroid +antibiotics), followed by analgesia alone 16(24.6\%), 8(12.3\%) treated with (analgesia +antibiotics), only one case treated by (analgesia + steroid +antibiotics +IVIG) as shown in (Table 8):

\section{$\underline{\text { Discussion }}$}

Henoch-Schonlein purpura is the most common vasculitis in the world. It is an acute immunoglobulin A (IgA) mediated disorder characterized by a generalized vasculitis involving the small vessels of the skin, the gastrointestinal tract, the kidneys, the joints, and rarely the lungs and the central nervous system (CNS).
In our study, 65 patients with HSP were evaluated in terms of their epidemiologic, clinical characteristics and their findings were compared with those reported from Mosul, Saudi Arabia, Turkey and other countries.

In our study The mean age was $6.00 \pm$ 2.729 years (range 1-12 years),this result in 
Web Site: $\underline{\text { https://jmed.utq.edu.iq }}$
Email:utjmed@utq.edu.iq

ISSN (Print):1992-92 18, ISSN (Online):1992-92 18

DOI: https://doi.org/10.32792/utq/utjmed/19/1/11

agreement with the result done in Mosul (Rabei M. EL-Dubooni ) ${ }^{(24)}$, in Saudi Arabia(Amer A. Lardhi) ${ }^{(25)}$, Florence Italy (Trapani et al.) ${ }^{(26)}$, Luga Spain (Calvino et al.) ${ }^{(14)}$, and Virginia USA (Saulsbury et al) (13) but disagree with the studies done in Turkey (7.9 \pm 2.9$)$ (An1l et al.) $)^{(27)},(7.1 \pm 3.3)$

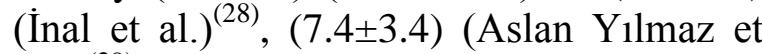
al) (29) and in Oulu Finland $(7.1 \pm 3.5)$ (Jauhola et al. $)^{(30)}$, the peak age between (26 years), it has been mentioned in most of text books.

In this study the male more affected than female, the male to female ratio was (1.3:1), this result in agreement with the results done in Mosul(Rabei M. EL-Dubooni )$^{(24)}$, Saudi Arabia(Amer A. Lardhi) ${ }^{(25)}$,( İnal et al.) ${ }^{(28)}$, Aslan Yilmaz et al ${ }^{(29)}$, Virginia USA (Saulsbury et al) ${ }^{(13)}$ and in Oulu Finland (Jauhola et al.) ${ }^{(30)}$, this information was mentioned in most of the text books, but disagree with the study was done in Luga Spain (Calvino et al.) ${ }^{(14)}$ More common in female than male $(0.85)$.

Peak incidence of the disease most frequently seen in Winter and less frequently in the Summer, the same in (Aslan Yilmaz et al $)^{(29)}$,Virginia USA(Saulsbury et al) ${ }^{(13)}$ and Italy (Trapani et al.) ${ }^{(23)}$, but not the same in other studies like in Saudi Arabia (Amer A. Lardhi) ${ }^{(25)}$, Turkey (Anil et al.) ${ }^{(27)}$ and Luga Spain (Calvino et al.) ${ }^{(14)}$ The peak incidences most frequently seen in autumn. Also in Turkey (İnal et al.) ${ }^{(28)}$ The peak incidence occurred in spring, these variations may be due to differences in environmental conditions that affecting the presence of triggering factors.
The etiology of the disease is unknown, but it may be triggered by some factors. In our study the most possible triggering factor was (URTI) 24(36.9\%), this result agreement with results done in Mosul(Rabei M. ELDubooni ) ${ }^{(24)}$, in Saudi Arabia(Amer A. Lardhi) ${ }^{(25)}$,Turkey( İnal et al. $)^{(28)}$, Virginia USA (Saulsbury et al) ${ }^{(13)}$ and Italy (Trapani et al.) ${ }^{(23)}$, Oulu Finland (Jauhola et al.) $)^{(30)}$ and Luga Spain (Calvino et al. $)^{(14)}$.

All patients in our study $65(100 \%)$ had skin manifestations and same result seen in the studies done in Mosul(Rabei M. ELDubooni ${ }^{(24)}$,Saudi Arabia(Amer A. Lardhi ${ }^{(25)}$,Turkey(İnal et al. $)^{(28)}$, Turkey $(\text { An1l et al. })^{(27)}$ Virginia USA (Saulsbury et al) (13) and Italy (Trapani et al.) ${ }^{(23)}$, Oulu Finland (Jauhola et al.) ${ }^{(30)}$ and Luga Spain (Calvino et al. ${ }^{(14)}$.It is well known that skin manifestation found in $100 \%$ of the patients.

In this study $46(70.8 \%)$ of patients had gastrointestinal involvement, near results found in Turkey (Aslan Yilmaz et al) ${ }^{(29}$ 'Luga Spain (Calvino et al.) ${ }^{(14)}$.but other studies showing different results like (Mosul(90.47\%)(Rabei M. EL-Dubooni )$^{(24)}$,Saudi Arabia(47\%)(Amer A.Lardhi) ${ }^{(25)}$,Turkey $(60 \%)$ (İnal et al.) ${ }^{(28)}$, Turkey (34\%) (An1l et al.) ${ }^{(27)}$, USA $(60 \%)$ (Saulsbury et al) ${ }^{(13)}$, Italy $(51 \%)$ (Trapani et al.) ${ }^{(23)}$ and Oulu Finland (57\%) (Jauhola et al. ${ }^{(30)}$.It may be associated with side effects of drugs that used in treatment of HSP like (NSAIDs).

Forty-three (66\%) patients had skeletal manifestations mostly ankle and knee involvement, closer percentage found in Mosul (Rabei M. EL-Dubooni) ${ }^{(24)}$, Saudi Arabia(Amer A. Lardhi) ${ }^{(25)}$,Turkey( İnal et 
Web Site: $\underline{\text { https://jmed.utq.edu.iq }}$

\author{
Email:utjmed@utq.edu.iq
}

ISSN (Print):1992-92 18, ISSN (Online):1992-92 18

DOI: https://doi.org/10.32792/utq/utjmed/19/1/11

al.) ${ }^{(28)}$, Turkey (Aslan Y1lmaz et al) ${ }^{(29)}$ and Virginia USA(Saulsbury et al $)^{(13)}$.but higher percentage found in (Luga Spain(78\%) (Calvino et al.) ${ }^{(14)}$, Oulu Finland $(90 \%)$

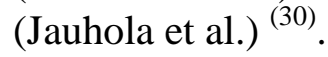

In this study $17(26.16 \%)$ had renal involvement, nearly similar were found in Saudi Arabia(Amer A. Lardhi) ${ }^{(25}$ ) and Turkey(Aslan Yilmaz et al) ${ }^{(29)}$,but differ with studies done in Mosul(35.11\%)(Rabei M. EL-Dubooni $)^{(24)}$, Luga Spain $(54 \%)$ (Calvino et al.) ${ }^{(14)}$, Italy (54\%) (Trapani et al.) ${ }^{(23) .}$ the rate of renal involvement in HSP varies between $20 \%$ and $60 \%$ in different studies ${ }^{(31)}$.

Testicular involvement in our study were (2 in 37 male) (5.4\%), nearly similar were found in Turkey (İnal et al.) ${ }^{(28)}$, Turkey (An1l et al.) ${ }^{(27)}$,USA(Saulsbury et al) ${ }^{(13)}$,but not the same with results in Saudi Arabia (7 in 46 male)(15\%)(Amer A. Lardhi) ${ }^{(25)}$, Turkey(13 in 90 male)(14\%)(Aslan Y1lmaz et al) ${ }^{(29)}$,Italy(23 in 114 male)(20\%)(Trapani et al.) ${ }^{(23)}$ And Oulu Finland (17 in 122 male) $(14 \%)$ (Jauhola et al. ${ }^{(30)}$.All results range between ( 2 to 38 percent); it has been mentioned in urogenital involvement.

The laboratory tests usually help in excluding other diseases and in evaluating renal function, but are not diagnostic for HSP, our data show increased ESR in (16 of 36 patients)(44\%) agreement with (Trapani et al) ${ }^{(23)}$ and Saudi Arabia(Amer A. Lardhi) ${ }^{(25)}$, increase CRP in (14 of 28 patients)(50\%),leukocytosis in $(61.5 \%)$, these are may be increase in any inflammatory condition, anemia (36.9\%) disagree with Saudi Arabia(Amer A. Lardhi) ${ }^{(25)}$,it may be related with GIT involvement rather than other conditions, thrombocytosis in (10.8\%) agreement with (Saudi Arabia(Amer A. Lardhi) ${ }^{(25)}$,no any patients had thrombocytopenia, just some cases had thrombocytosis, it has been mentioned in text books, fecal occult blood positive (10 in 29 patients)(34\%) near results in Turkey( İnal et al.) ${ }^{(28)}$,(Aslan Yilmaz et al) ${ }^{(29)}$,(Perue et al) ${ }^{(32)}$ and USA(Saulsbury et al) ${ }^{(13)}$,but disagree with results of the following studies (Luga Spain $(15 \%)$ (Calvino et al.) ${ }^{(14)}$, Italy $(20 \%)$ (Trapani et al.) $^{(23)}$ and Oulu Finland (22\%).

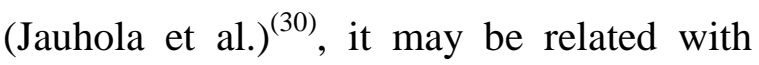
more using (NSAIDs) in treatment of HSP patients rather than related with this disease.

In our study renal function tests were sent for 35 patients, all of them were normal; rarely patients develop renal failure it has mentioned in most text books.

In this study ASO titer were sent for few cases, all of them were normal, this result disagree with (Trapani et al.) ${ }^{(23)}$ Were increased ASO titers in half of patients (54 in 108 patients)(50\%), also in Saudi Arabia (Amer A. Lardhi) ${ }^{(25)}$ ASO titers increased in (11 of 24 patients)(45.8\%), this is support that in our country most infections are viral infections, but in others, Streptococcus is a common cause of (URTI).

In our study the patients treated in different ways (20 of 65 patients)( $30.8 \%$ ) treated by (analgesia+ steroid), (20 of 65 patients)( $30.8 \%$ ) treated with (analgesia+ steroid+ antibiotics),( 16 of 65 patients)( $24.6 \%)$ treated with analgesia alone, in other studies the treatment were different for example in (Trapani et al.) ${ }^{(23)}$ NSAIDs were 
Web Site: https://jmed.utq.edu.iq

ISSN (Print):1992-92 18, ISSN (Online):1992-92 18

DOI: https://doi.org/10.32792/utq/utjmed/19/1/11
Email:utjmed@utq.edu.iq administered in $15 \%$ of children, who complained of severe arthralgias or arthritis, and OCS were used in $12 \%$ of patients, who suffered from severe abdominal pain or

\section{Conclusion}

From the results we can conclude the following points:

1. There were no major differences in the epidemiological and clinical features of HSP in Sulaimaniyah with that most of similar studies done elsewhere.

2. The diagnosis of HSP in our study mostly based on clinical findings.

3. Children in this study had more GIT involvement than arthritis. Those who developed renal involvement had mostly asymptomatic microscopic hematuria.

4. HSP patients could have various clinical symptoms and quite rare complications in our locality.

5. Many patients had been treated with (antibiotics, steroid, analgesia), while the scientific treatment better to be only simple analgesia, bed rest and rehydration with treatment of complications if they developed. renal involvement, and in Saudi Arabia (Amer A. Lardhi) ${ }^{(25)}$ most of the patients with HSP require no treatment other than supportive measures, just ten (13\%) patients received steroid for GI and renal involvement.

\section{$\underline{\text { Recommendation }}$}

1. Patients who are possible to have HSP better to be seen by pediatrician to avoid wrong diagnosis or wrong management.

2. Education of the public about the disease and it is complications in order to be aware about the disease and to enhance cooperation between parents and the medical staff for better outcome.

3. Steroids are a possible line of treatment in HSP ( still questionable ) but they are better not be used routinely if not indicated, because of their side effects.

4. To identify patients who may develop renal involvement later on, we recommend a follow up screening tests like (urinalysis, renal function and blood pressure measurements) by the out patients clinics during subsequent well-child visits or by the pediatrician follow up examination.

\section{$\underline{\text { Refrences }}$}

1. Blanco R, Martínez-Taboada VM et al. Henoch-Schönlein purpura in adulthood and childhood: two different expressions of the same syndrome. Arthritis Rheum. 1997;40(5):859864.

2. Szer IS. Henoch-Schönlein purpura. Curr Opin Rheumatol. Jan 1994; 6(1):25-31.

3. Henoch E. Lectures on children's diseases. Second volume (translated from fourth edition). The New Sydenham Society,London. 1889:373-376. 
Web Site: $\underline{\text { https://jmed.utq.edu.iq }}$
Email:utjmed@utq.edu.iq

\section{ISSN (Print):1992-92 18, ISSN (Online):1992-92 18 \\ DOI: https://doi.org/10.32792/utq/utjmed/19/1/11}

4. Miller ML, Pachman LM. Henoch-Schonlein purpura. In: Kliegmen RM, Jenson HB, Behrman RE, eds. Nelson Textbook of Pediatrics. 19th ed. Philadelphia: Saunders; 2011; p868871.

5. Levy M, Broyer M, Arsan A, et al. Anaphylactoid purpura nephritis in childhood: natural history and immunopathology. Adv Nephrol Necker Hosp 1976; 6:183.

6. Bayram C, Demircin G, Erdo $\curvearrowright$ an O, et al. Prevalence of MEFV gene mutations and their clinical correlations in Turkish children with Henoch-Schönlein purpura. Acta Paediatr 2011; 100:745.

7. Dillon MJ. Henoch-Schönlein purpura: recent advances. Clin Exp Rheumatol 2007; 25:S66.

8. Rigante D, Castellazzi L, Bosco A, Esposito S. Is there a crossroad between infections, genetics, and Henoch-Schönlein purpura?. Autoimmun Rev 2013; 12(10):1016-1021.

9. Reinauer S, Megahed M,et al Schönlein-Henoch purpura associated with gastric Helicobacter pylori infection. J Am Acad Dermatol 1995; 33: 876-879.

10. Kim C J, Woo Y J,et al, Henoch-Schonlein purpura nephritis associated with EpsteinBarr virus infection in twins. Pediatr Nephrol 2004; 19:247-248.

11. Aktas B, Topcuoglu P,et al, Severe henoch-schonlein purpura induced by cytarabine. Ann Pharmacother 2009; 4:792-793.

12. Lau K, Suzuki H, Novak J \& Wyatt R, Pathogenesis of Henoch-Schönlein purpura nephritis. Pediatr Nephrol 2010; 25: 19-26.

13. Saulsbury F, Henoch-Schönlein purpura in children: report of 100 patients and review of the literature. Medicine (Baltimore) 1999; 78(6): 395-409

14. Calvino M, Llorca J,et al Henoch-Schönlein purpura in children from Northwestern Spain: a 20-year epidemiologic and clinical study. Medicine (Baltimore) 2001; 80: 279-290.

15. Saulsbury F, Alterations in the O-linked glycosylation of IgA1 in children with HenochSchonlein purpura. J Rheumatol 1997; 24: 2246-2249.

16. Kraft DM, Mckee D, Scott C. "Henoch-Schönlein purpura: a review".American Family Physician 1998; 58 (2): 405-408, 411.

17. Simon Steddon,Neil Ashman,Alisain Chesser et al,kidney in systemic diseases,chapter 8,Handbook of nephrology and hypertention, Oxford, $2^{\text {nd }}$ edition,2014;650-651.

18. Chamberlain RS, Greenberg LW. Scrotal involvement in Henoch-Schönlein purpura: a case report and review of the literature. Pediatr Emerg Care 1992; 8:213.

19. Lind J, Mackay A \& Withers S Henoch-Schönlein purpura and priapism. J Paediatr Child Health 2002; 38: 526-527.

20. Sandell J, Ramanan R \& Shah D, Penile involvement in Henoch-Schonlein purpura. Indian J Pediatr 2002; 69: 529-530.

21. Garzoni L, Vanoni F,et al ,Nervous system dysfunction in Henoch-Schönlein syndrome: systematic review of the literature. Rheumatology (Oxford) 2009; 48: 1524-1529.

22. Wright W K, Krous H F, Griswold W R,et al. Pulmonary vasculitis with hemorrhage in anaphylactoid purpura. Pediatr Pulmonol 1994; 17: 269-271.

23. Trapani S, Micheli A, Grisolia F, et al. Henoch Schonlein purpura in childhood: epidemiological and clinical analysis of 150 cases over a 5-year period and review of literature. Semin Arthritis Rheum 2005; 35(3):143-153. 
Web Site: $\underline{\text { https://jmed.utq.edu.iq }}$

\section{Email:utjmed@utq.edu.iq}

\section{ISSN (Print):1992-92 18, ISSN (Online):1992-92 18 \\ DOI: https://doi.org/10.32792/utq/utjmed/19/1/11}

24. Rabei M. EL-Dubooni, A clinical Study Of Henoch - Schonlein Purpura In Mosul With follow up of renal involved cases Tikrit Medical Journal 2006; 12(1):85-88.

25. Amer A. Lardhi, Henoch-Schonlein purpura in children from the eastern province of Saudi Arabia, Saudi Med J 2012; Vol. 33 (9): 973-978

26. Trapani S, Micheli A, Grisolia F, et al. Henoch Schonlein purpura in childhood: epidemiological and clinical analysis of 150 cases over a 5-year period and review of literature. Semin Arthritis Rheum 2005; 35(3):143-153.

27. Anıl M, Aksu N, Kara OD et al. Henoch Schönlein purpura in children from Western Turkey: A retrospective analysis of 430 cases. Turk J Pediatr 2009; 51(5): 429-436.

28. İnal A, Y1lmaz M, Kendirli SG et al. The clinical characteristics of children with Henoch Schönlein purpura. Erciyes Medical Journal 2009; 31(2): 153-161.

29. Aslan Y1lmaz, Mehmet Baha Aytaç, Zelal Ekinci, Retrospective assessment of children with Henoch-Schonlein Purpura in and around Kocaeli Province and comparison with literature, Erciyes Med J 2014 36(2): 62-67.

30. Jauhola O, Ronkainen J, Koskimies $\mathrm{O}$ et al. Clinical course of extrarenal symptoms in Henoch Schönlein purpura: a 6-month prospective study. Arch Dis Child 2010; 95(11): 871-876.

31. Narchi H. Risk of long renal impairment and duration of follow-up recommended for Henoch-Schonlein purpura with normal or minimal urinary findings. A systematic review.Arch Dis Child 2005; 90: 916-920.

32. Peru H, Soylemezoglu O, Bakkaloglu SA et al. Henoch Schonlein purpura in childhood: clinical analysis of 254 cases over a 3-year period. Clin Rheumatol 2008; 27(9): 1087-1092. 
Thi-Qar Medical Journal (TQMJ):Vol.(19), No.(1), 2020

Web Site: $\underline{\text { https://jmed.utq.edu.iq }}$

Email:utjmed@utq.edu.iq

ISSN (Print):1992-92 18, ISSN (Online):1992-92 18

DOI: https://doi.org/10.32792/utq/utjmed/19/1/11

\section{مرض فرفورة هينوخ عند الاطفال بين ا_ Y ا عام في مدينة السليمانية \العراق}

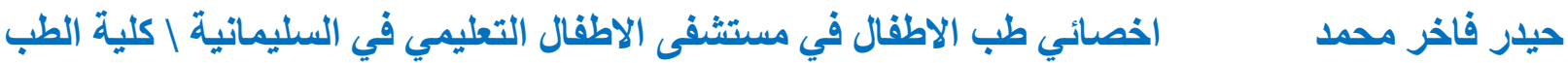
| جامعةٌ السليماتية

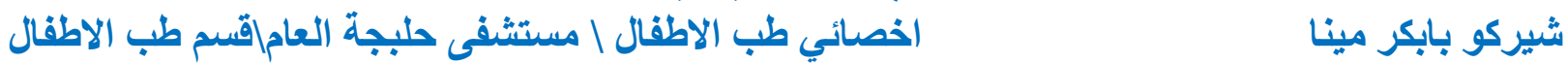

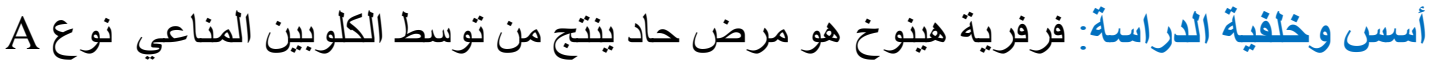

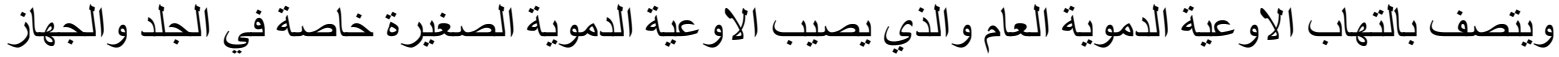

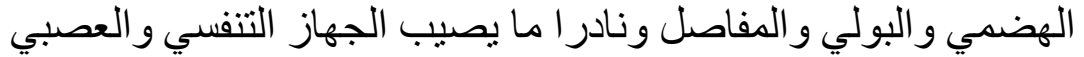

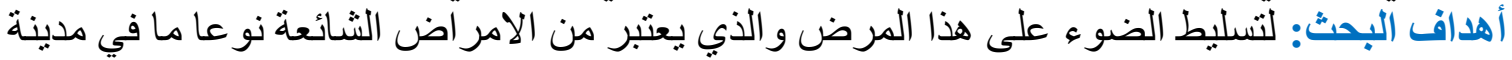

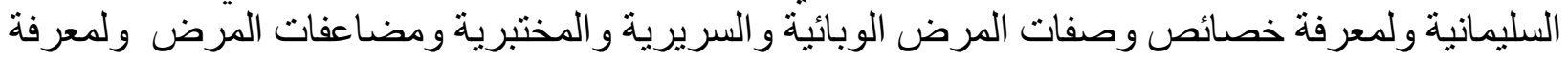

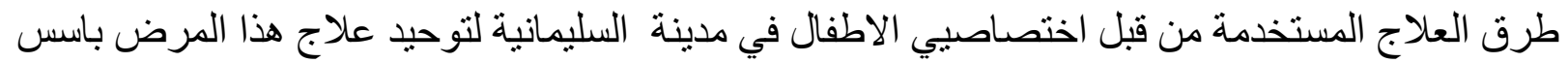
علمية صحيحة.

المرضى وطرق البحث: خمسة وستون مريضا مصابين بفرفرية هينو خ ادخلوا الى مستشفى السليمانية

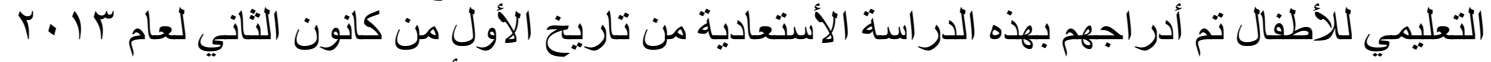

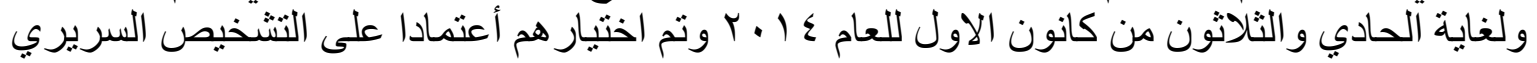

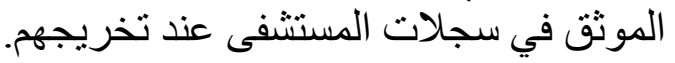

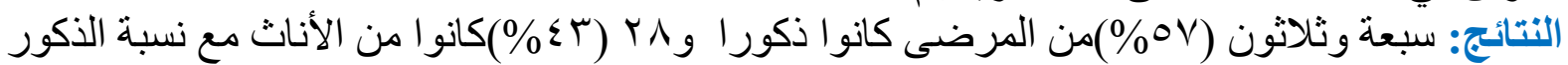

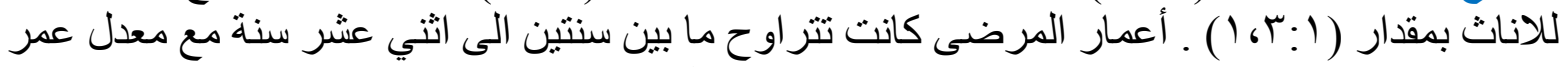

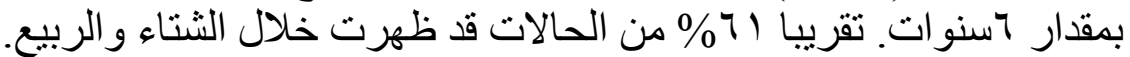

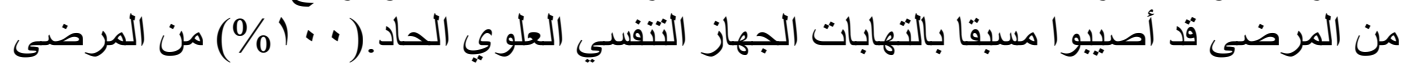
$(\% 36,9)$

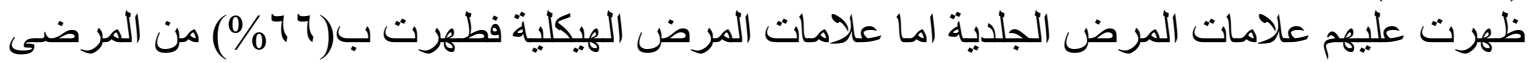

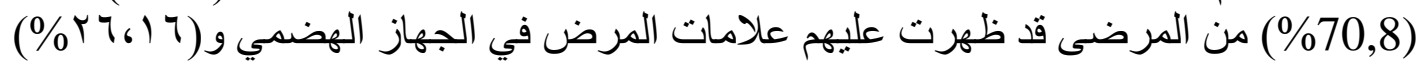

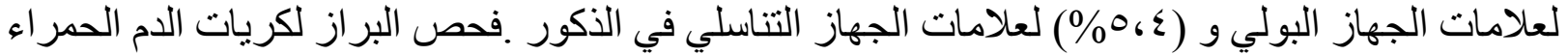

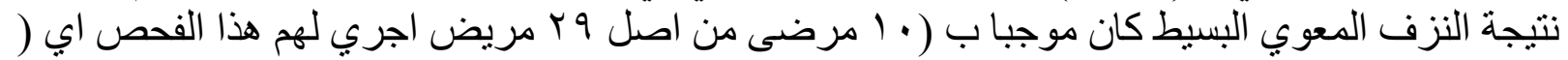
. $(\%$ \% ، 0

واحد واربعون مريض تم استخدام مركبات الستيرويد في علاجهم.

الاستنتاجات: ليس هناك فروقات كبيرة في صفات المرض الوبائية والسريرية و المختبرية في السليمانية

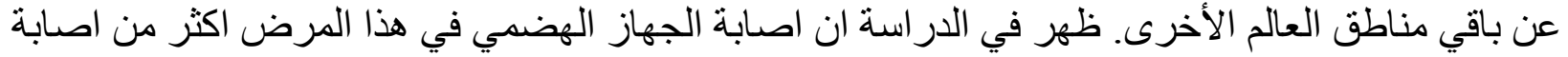

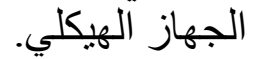
معظم المرضى في هذه الدراسة تم استخدام مركبات الستيرويد في علاجهم. 